\title{
Evolution of tree stem taper in Pinus taeda stands
}

\author{
Evolução do afilamento do tronco em povoamentos de Pinus taeda
}

\author{
Sintia Valerio Kohler $^{\mathrm{I}^{*}}$ Henrique Soares Koehler ${ }^{\mathrm{II}}$ \\ Afonso Figueiredo Filho ${ }^{\text {III }}$ Julio Eduardo Arce ${ }^{\text {IV }}$ Sebastião do Amaral Machado ${ }^{\text {IV }}$
}

\section{ABSTRACT}

This study aimed to evaluate the evolution of stem taper of trees in Pinus taeda stands using stem analysis data from 126 and 120 trees sampled from established stands in Paraná and Santa Catarina States, respectively. The integer and fractional power polynomial was fitted to estimate diameters inside bark along the stem and was used to construct taper curves by age class. The model identity test was applied to verify the change in stem form of trees. The evolution of natural and artificial form factors in the trees was also analyzed. The curves constructed from the fitted taper functions and form factors showed that the stems become more cylindrical with increasing age; the identity test indicated that, in general, the taper curves statistically differ between themselves. This showed that stratifying the data into age classes for fitting in taper functions can produce more accurate assortment estimates.

Key words: stem analysis, form factor, tapering.

RESUMO

O objetivo desta pesquisa foi avaliar a evolução do afilamento dos fustes de árvores em povoamentos de Pinus taeda, utilizando dados de análise de tronco de 126 e 120 árvores amostradas, respectivamente, em plantios estabelecidos nos estados do Paraná e de Santa Catarina. O polinômio de potências inteiras e fracionárias foi ajustado para estimativa dos diâmetros sem casca ao longo do tronco e usado para construção de curvas de afilamento por classe de idade. $O$ teste de identidade de modelos foi aplicado para verificar a mudança na forma do tronco das árvores. Foi analisada também, a evolução do fator de forma natural e artificial das árvores. As curvas construidas a partir das funções de afilamento ajustadas e os fatores de forma mostram que os troncos se tornam mais cilindricos com o aumento da idade. $O$ teste de identidade indicou que, em geral, as curvas de afilamento diferem estatisticamente entre si. Isso evidencia que a estratificação dos dados em classes de idades nos ajustes de funções de afilamento pode produzir estimativas mais acuradas do sortimento.

Palavras-chave: análise de tronco, fator de forma, afilamento do tronco.

\section{INTRODUCTION}

Trees have a certain type of stem form that can be highly variable and may differ according to the species, site conditions, initial density, silvicultural treatments applied, and sociological position where each tree develops. It also varies throughout age as a natural developmental phenomenon or results from phases of relative competition with neighboring trees (LARSON, 1963; FINGER et al., 1995).

Stem taper can be defined as the relative rate of change in stem diameter with increasing tree height; this change is a natural trend for the species and can be expressed using a mathematical function. According to MACHADO (1982), age affects stem taper; the older a tree is, the less taper it has. The form changes quite rapidly at young ages, whereas it is slower at advanced ages (FRIEDL, 1989).

Variation in the stem form of the trees with increasing age can be expressed by taper functions

\footnotetext{
IPrograma de Pós-graduação em Engenharia Florestal, Universidade Federal do Paraná (UFPR), Av. Pref. Lothário Meissner, 632, Jardim Botânico, 80210-170, Curitiba, PR, Brasil. E-mail: sintiakohler@yahoo.com.br. "Corresponding author.

IDepartamento de Fitotecnia e Fitossanitarismo, Universidade Federal do Paraná (UFPR), Curitiba, PR, Brasil.

IIIDepartamento de Engenharia Florestal, Universidade Estadual do Centro-Oeste (UNICENTRO), Irati, PR, Brasil.

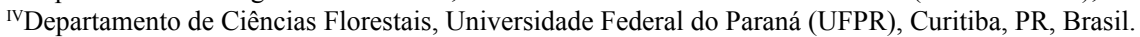
Received 01.10.14 Approved 02.15.16 Returned by the author 04.15.16 CR-2014-0021.R2
} 
and form factors. Taper functions are equations that describe tree taper, representing the diametric variation along the stem as a function of diameter at breast height (DBH) and total height. In contrast, the form factor is represented by the ratio between tree volume and the volume of a geometric solid, usually a cylinder with the same diameter and height as the tree.

Many researchers have studied tree form, such as FIGUEIREDO FILHO et al. (1996), FISCHER et al. (2001), MACHADO et al. (2004), KOHLER et al. (2013), MÔRA et al. (2014), and FIGUEIREDO FILHO et al. (2015). LARSON (1963) broadly discussed stem form. BURGER et al. (1980) studied form development in Araucaria based on the Hohenadl form factor by age, concluding that the geometric form of the trees is constantly improving. FRIEDL (1989) analyzed the effect of age on stem form in Araucaria, detecting a strong effect of age on form. FERREIRA (1999) studied the effect of age on absolute and natural form factors, concluding that both are highly affected by age. FIGUEIREDO FILHO et al. (2014) evaluated the development of form in Araucaria angustifolia stands. They fitted a fifth-degree polynomial for age classes and the resulting curves indicated that stem form improves with age. The authors reported this same trend with the form factor.

Understanding stem form and its dynamics over time is an important tool for identifying the appropriate moment in which thinning or final felling should be carried out in forest plantations. This is because stem form defines a forest's assortment, and consequently, its economic value. Thus, this study sought to evaluate the evolution of stem taper in Pinus taeda trees using taper functions and form factors, and evaluate changes in stem form with age using the model identity test.

\section{MATERIALS AND METHODS}

\section{Description of the data}

The data were obtained using the complete stem analysis technique on trees from Pinus taeda stands, with 126 trees (between 7 and 18 years old) sampled in South-Central Paraná state and 120 trees (between 11 and 23 years old) sampled in the mountainous region of Santa Catarina State, Brazil. In both cases, this study sought to sample trees that represent the diametric variation of the stands.

\section{Complete stem analysis}

The sampled trees were felled, and 11 disks were removed along each stem, at absolute heights of 0.1 and $1.3 \mathrm{~m}$ and relative heights of $15 \%, 25 \%, \ldots$, $95 \%$ of the total tree height.

The rings were measured with LINTAB $^{\circledR}$ 6.0 equipment, using the TSAP (Time Series Analysis Program) program to perform the measurements. The stem analysis data were processed with the FlorExel ${ }^{\circledR}$ program, which generates diameters at different heights along the stem for the tree's current age and all past ages. The data generated with the stem analysis technique are shown in table 1.

Fitting the taper functions

To estimate the diameters along the tree stems at various ages, the data were fitted to an integer and fractional power polynomial (1) proposed by HRADETZKY (1976).

$\frac{\mathrm{d}_{\mathrm{i}}}{\mathrm{DBH}}=\beta_{0}+\beta_{1}\left(\frac{\mathrm{h}_{\mathrm{i}}}{\mathrm{h}}\right)^{\mathrm{p} 1}+\beta_{2}\left(\frac{\mathrm{h}_{\mathrm{i}}}{\mathrm{h}}\right)^{\mathrm{p} 2}+\ldots \beta_{\mathrm{n}}\left(\frac{\mathrm{h}_{\mathrm{i}}}{\mathrm{h}}\right)^{\mathrm{p}}+\varepsilon_{\mathrm{i}}$

where: $\beta_{i}=$ model coefficients; $d_{i}=$ diameter inside bark at different heights $\left(h_{i}\right)$ along the stem $(\mathrm{cm}) ; \mathrm{DBH}=$ diameter inside bark at $1.3 \mathrm{~m}$ above ground $(\mathrm{cm}) ; \mathrm{h}_{\mathrm{i}}=$ height $(\mathrm{m})$ at a certain diameter $\mathrm{d}_{\mathrm{i}}$; $\mathrm{ht}=$ total tree height $(\mathrm{m}) ; \mathrm{p}_{\mathrm{i}}=$ model powers; $\varepsilon_{\mathrm{i}}=$ random errors.

Table 1 - Dendrometric characteristics of stem profiles (n) of Pinus taeda trees generated by the complete stem analysis technique for the trees sampled in the Paraná and Santa Catarina States.

\begin{tabular}{|c|c|c|c|c|c|c|}
\hline \multirow{2}{*}{ Age Classes (years) } & \multicolumn{3}{|c|}{-Paraná } & \multicolumn{2}{|c|}{--Santa Catarina } & \multirow[b]{2}{*}{ Average ht (m) } \\
\hline & $\mathrm{n}$ & Average DBH $(\mathrm{cm})$ & Average ht (m) & $\mathrm{n}$ & Average DBH $(\mathrm{cm})$ & \\
\hline 7 to 9 & 307 & 14.9 & 11.1 & 324 & 17.8 & 12.2 \\
\hline 10 to 12 & 183 & 20.5 & 15.0 & 297 & 21.8 & 16.5 \\
\hline 13 to 15 & 61 & 25.1 & 18.8 & 189 & 25.2 & 20.8 \\
\hline 16 to 18 & 25 & 31.9 & 23.1 & 108 & 28.6 & 23.5 \\
\hline 19 to 23 & - & - & - & 112 & 33.7 & 25.8 \\
\hline
\end{tabular}

$\mathrm{n}$ : Each age of the trees stem generates a different profile with complete stem analysis technique; DBH: diameter inside bark at $1.3 \mathrm{~m}$ above the ground; ht: total tree height. 
The following powers were tested for the polynomial: $0.005,0.09,0.08,0.07,0.06,0.05,0.04$, $0.03,0.02,0.01,0.9,0.8,0.7,0.6,0.5,0.4,0.3,0.2,0.1$, $1,2,3,4,5,10,15,20$, and 25 , and the variables were also selected using the Stepwise statistical procedure.

After selecting the variables, the model was initially fitted for the entire sample, i.e., all of the data at various ages. Next, the database was stratified into age classes and the model was again fitted to each class. Thus, the fits were performed using the pairs of height and diameter along the stem at different age classes, where when $d_{i} / \mathrm{DBH}$ is equal to zero, $h_{i} / \mathrm{ht}$ is equal to 1 . The following age classes were defined: 7 to 9,10 to 12,13 to 15 and 16 to 18 years old for the state of Paraná and 7 to 9,10 to 12,13 to 15,16 to 18 and 19 to 23 years old for the state of Santa Catarina, Brazil. These classes were defined according to the "utility" management regime, which generally adopts thinning and final felling at ages similar to these classes.

Taper evolution

Stem profiles at each age class were drawn using the taper equations. Usually, taper curves are only visually analyzed. In this study, it sought to performed a less subjective evaluation of the curves, statistically testing the differences among distinct age class curves in order to determine if it would be possible to group some of these age classes.

For this, it was employed the test proposed by GRAYBILL (1976) and demonstrated by REGAZZI (1993). This test compared regression equations, assessing whether there is a difference between the sum of the regression squares fitted for each age class and the sum of the regression squares fitted for the set of all of the ages based on the analysis of variance and $\mathrm{F}$ test, i.e., testing whether or not it is necessary to develop taper equations, stratifying the data into age classes. GRAYBILL (1976) developed this test to verify the equality of a set of regression equations, testing the following null and alternative hypotheses: $\mathrm{H}_{0}: \underline{\beta 1}=\underline{\beta} 2=$ $\ldots=\underline{\beta} n$ (all of the " $n$ " equations are identical); $\mathrm{H}_{1}: \underline{\beta} \mathbf{i} \neq \underline{\beta j}$, for at least one $i \neq j$ (the " $n$ " equations are not identical).

Failure to reject $\mathrm{H}_{0}$ allows us to conclude at a given significance level that the " $n$ " equations do not statistically differ among themselves, i.e., the equations fitted with the estimates of the common parameters could be used as an estimate for the other equations involved.

Evolution of the form factor

The artificial and natural form factors of each tree were calculated at all of the ages studied. Based on the mean form factor by age class, it was possible to graphically view their development over time.

\section{RESULTS AND DISCUSSION}

Fitting the taper functions

The stepwise statistical procedure selected the same powers for the unstratified data (all ages) for the states of Paraná and Santa Catarina, which were then inserted into equation 2 . This was also observed in most of the fittings by age class, and thus the same powers were adopted for all of the age classes to facilitate the subsequent analyses.

$$
\frac{d_{i}}{D B H}=\beta_{0}+\beta_{1}\left(\frac{h_{i}}{h}\right)+\beta_{2}\left(\frac{h_{i}}{h}\right)^{0.2}+\beta_{3}\left(\frac{h_{i}}{h}\right)^{3}+\beta_{4}\left(\frac{h_{i}}{h}\right)^{0.005}+\beta_{5}\left(\frac{h_{i}}{h}\right)^{2}
$$

Table 2 shows the coefficients and statistics for the stratified and unstratified data for the states of Paraná and Santa Catarina. Statistics reported in fitting the stratified and unstratified data from Paraná and Santa Catarina exhibited excellent (approximately 0.99) determination coefficients $\left(\mathrm{R}^{2}\right)$ and a standard error of estimate $\left(\mathrm{S}_{\mathrm{yx}} \%\right)$ lower than $8.4 \%$, indicating the model's adequate fit to the data.

The standard error of estimate was slightly higher in the younger age classes, decreasing in the following classes, suggesting that the data were more homogeneous with increasing age. This same trend was reported by FRIEDL (1989), who fit taper models to Araucaria angustifolia trees at different ages and noted that fitting accuracy improved somewhat with increasing age, relating this trend to the better distribution of the points sampled in the profile as tree height increased with age and to the change in tree form that occurs with increasing age.

The graphical distribution of residuals for the age classes is shown in figure 1. The residuals became more homogeneous in the older age classes; this characteristic was present in both data groups. The equations also exhibited a small trend in underestimating the diameters closest to total tree height; this characteristic was more pronounced in the data from Paraná.

\section{Taper evolution curves}

The curves obtained are shown in figure 2, where the curves are steeper within the first years, indicating that there was greater stem taper at younger ages. Over time, the curves became less inclined, which indicates better distribution of stem growth, i.e., the trees became less tapered. BURGER et al. (1980) reported similar results in fitting a fifth-degree polynomial to obtain relative taper curves at the different ages of Araucaria angustifolia. These authors reported changes in stem form with increasing age and concluded that the 
Table 2 - Coefficients and statistics of the fitted taper functions by age classes for Pinus taeda stands in the Paraná and Santa Catarina States.

\begin{tabular}{|c|c|c|c|c|c|c|c|c|c|c|c|c|}
\hline \multirow{3}{*}{$\begin{array}{l}\text { Age Classes } \\
\text { (years) }\end{array}$} & \multirow{3}{*}{ Obs. } & \multirow{3}{*}{$\mathrm{R}^{2}$} & \multirow{3}{*}{$\mathrm{S}_{\mathrm{yx}}(\%)$} & - -Par & á----------- & \multirow{3}{*}{$\frac{\text { Value } P}{0 \mathrm{E}+00}$} & \multirow{3}{*}{$\mathrm{n}$} & \multirow{3}{*}{$\mathrm{R}^{2}$} & \multirow{3}{*}{$\mathrm{S}_{\mathrm{yx}}(\%)$} & Cat & la---------- & \multirow{3}{*}{$\frac{\text { Value } P}{0 \mathrm{E}+00}$} \\
\hline & & & & \multicolumn{2}{|c|}{ Coefficients } & & & & & \multicolumn{2}{|c|}{ Coefficients } & \\
\hline & & & & $\mathrm{b}_{0}$ & 1.2239 & & & & & $b_{0}$ & 1.1614 & \\
\hline \multirow{5}{*}{ General $^{*}$} & \multirow{5}{*}{5570} & \multirow{5}{*}{0.98} & \multirow{5}{*}{8.3} & $\mathrm{~b}_{1}$ & 0.1742 & 2E-06 & \multirow{5}{*}{10036} & \multirow{5}{*}{0.98} & \multirow{5}{*}{7.6} & $b_{1}$ & 0.0534 & $1 \mathrm{E}-02$ \\
\hline & & & & $\mathrm{b}_{2}$ & -0.9085 & $1 \mathrm{E}-274$ & & & & $\mathrm{~b}_{2}$ & -0.6896 & $0 \mathrm{E}+00$ \\
\hline & & & & $\mathrm{b}_{3}$ & -2.6342 & 8E-161 & & & & $b_{3}$ & -1.7573 & 5E-206 \\
\hline & & & & $\mathrm{b}_{4}$ & 0.3429 & 2E-193 & & & & $\mathrm{b}_{4}$ & 0.2509 & 1E-304 \\
\hline & & & & $\mathrm{b}_{5}$ & 1.8272 & $4 \mathrm{E}-123$ & & & & $b_{5}$ & 0.9891 & 5E-106 \\
\hline \multirow{6}{*}{7 to 9} & \multirow{6}{*}{2723} & \multirow{6}{*}{0.99} & \multirow{6}{*}{8.4} & $\mathrm{~b}_{0}$ & 1.2430 & $0.0 \mathrm{E}+00$ & \multirow{6}{*}{2586} & \multirow{6}{*}{0.99} & & $\mathrm{~b}_{0}$ & 1.1685 & $0.0 \mathrm{E}+00$ \\
\hline & & & & $\mathrm{b}_{1}$ & 0.0436 & $4.6 \mathrm{E}-01$ & & & & $b_{1}$ & -0.3224 & $3.7 \mathrm{E}-17$ \\
\hline & & & & $\mathrm{b}_{2}$ & -0.9094 & $1.2 \mathrm{E}-10$ & & & & $b_{2}$ & -0.5356 & $1.3 \mathrm{E}-91$ \\
\hline & & & & $\mathrm{b}_{3}$ & -2.5271 & $3.2 \mathrm{E}-60$ & & & 5.9 & $b_{3}$ & -1.5219 & $5.4 \mathrm{E}-53$ \\
\hline & & & & $\mathrm{b}_{4}$ & 0.3597 & $3.2 \mathrm{E}-84$ & & & & $\mathrm{~b}_{4}$ & 0.2127 & $2.8 \mathrm{E}-72$ \\
\hline & & & & $\mathrm{b}_{5}$ & 1.8286 & $5.2 \mathrm{E}-50$ & & & & $\mathrm{~b}_{5}$ & 1.0243 & $6.5 \mathrm{E}-39$ \\
\hline & & & & $\mathrm{b}_{0}$ & 1.2074 & $0.0 \mathrm{E}+00$ & & & & $b_{0}$ & 1.1527 & $0.0 \mathrm{E}+00$ \\
\hline & & & & $\mathrm{b}_{1}$ & 0.2711 & 5.3E-07 & & & & $b_{1}$ & -0.0095 & $7.6 \mathrm{E}-03$ \\
\hline & 1808 & 009 & 80 & $\mathrm{~b}_{2}$ & -0.9235 & $9.3 \mathrm{E}-126$ & 2041 & 009 & 57 & $\mathrm{~b}_{2}$ & -0.6526 & 2.7E-189 \\
\hline 10 to 12 & 1898 & 0.99 & 8.0 & $\mathrm{~b}_{3}$ & -2.8239 & $1.8 \mathrm{E}-81$ & 2941 & 0.99 & 5.7 & $b_{3}$ & -1.7894 & $1.5 \mathrm{E}-99$ \\
\hline & & & & $\mathrm{b}_{4}$ & 0.3451 & 4.4E-87 & & & & $\mathrm{b}_{4}$ & 0.2423 & $9.5 \mathrm{E}-131$ \\
\hline & & & & $\mathrm{b}_{5}$ & 1.9478 & $3.0 \mathrm{E}-62$ & & & & $b_{5}$ & 1.0664 & $5.7 \mathrm{E}-58$ \\
\hline & & & & $\mathrm{b}_{0}$ & 1.2009 & $0.0 \mathrm{E}+00$ & & & & $\mathrm{~b}_{0}$ & 1.1546 & $0.0 \mathrm{E}+00$ \\
\hline & & & & $\mathrm{b}_{1}$ & 0.4206 & $6.7 \mathrm{E}-09$ & & & & $b_{1}$ & 0.1569 & 4.4E-06 \\
\hline & & & & $\mathrm{b}_{2}$ & -0.9664 & $5.8 \mathrm{E}-73$ & & & & $\mathrm{~b}_{2}$ & -0.7134 & $6.7 \mathrm{E}-182$ \\
\hline 13 to 15 & 659 & 0.99 & 6.0 & $\mathrm{~b}_{3}$ & -2.7111 & $6.1 \mathrm{E}-41$ & 2006 & 0.99 & 5.4 & $b_{3}$ & -1.8182 & $7.4 \mathrm{E}-85$ \\
\hline & & & & $\mathrm{b}_{4}$ & 0.3455 & $9.0 \mathrm{E}-49$ & & & & $\mathrm{~b}_{4}$ & 0.2514 & $3.3 \mathrm{E}-117$ \\
\hline & & & & $\mathrm{b}_{5}$ & 1.7176 & $2.3 \mathrm{E}-27$ & & & & $\mathrm{~b}_{5}$ & 0.9742 & $3.8 \mathrm{E}-41$ \\
\hline & & & & $\mathrm{b}_{0}$ & 1.1676 & $1.5 \mathrm{E}-292$ & & & & $\mathrm{~b}_{0}$ & 1.1597 & $0.0 \mathrm{E}+00$ \\
\hline & & & & $\mathrm{b}_{1}$ & 0.4962 & $3.7 \mathrm{E}-10$ & & & & $b_{1}$ & 0.2647 & 9.7E-09 \\
\hline & 200 & 000 & 51 & $\mathrm{~b}_{2}$ & -0.9064 & $3.6 \mathrm{E}-49$ & 1106 & 000 & 57 & $b_{2}$ & -0.7656 & $1.2 \mathrm{E}-116$ \\
\hline 16 to 18 & 290 & 0.99 & 5.1 & $\mathrm{~b}_{3}$ & -2.9501 & 8.8E-38 & 1196 & 0.99 & 5.7 & $b_{3}$ & -1.7620 & $2.0 \mathrm{E}-45$ \\
\hline & & & & $\mathrm{b}_{4}$ & 0.3131 & $1.5 \mathrm{E}-32$ & & & & $\mathrm{~b}_{4}$ & 0.2623 & $1.7 \mathrm{E}-72$ \\
\hline & & & & $\mathrm{b}_{5}$ & 1.8743 & $4.6 \mathrm{E}-27$ & & & & $b_{5}$ & 0.8382 & $4.4 \mathrm{E}-18$ \\
\hline & & & & & & & & & & $b_{0}$ & 1.1767 & $0.0 \mathrm{E}+00$ \\
\hline & & & & & & & & & & $b_{1}$ & 0.4831 & $5.7 \mathrm{E}-24$ \\
\hline & & & & & & & & & & $b_{2}$ & -0.9031 & $3.0 \mathrm{E}-148$ \\
\hline 19 to 23 & & & & & & & 1307 & 0.99 & 6.2 & $b_{3}$ & -1.9432 & $7.1 \mathrm{E}-53$ \\
\hline & & & & & & & & & & $\mathrm{b}_{4}$ & 0.3035 & $1.1 \mathrm{E}-89$ \\
\hline & & & & & & & & & & $b_{5}$ & 0.8712 & 5.6E-19 \\
\hline
\end{tabular}

Fit with all data without stratification by age classes; Obs = number of observations used in the adjustment; Variables selected by the statistical procedure Stepwise: hi / ht; (hi / ht) 0.2; (hi / ht) 3; (hi / ht) 0005; (hi / ht) 2; hi = height along the stem (m); ht = total height (m); $\mathrm{R}^{2}=$ coefficient of determination; $\mathrm{S}_{\mathrm{YX}}(\%)=$ standard error of the estimate.

stem taper of the trees at six years old was still paraboloid along the entire stem, changing to neiloid in the lower portion, whereas the paraboloid form was accentuated at the top, leading the authors to determine that the taper of the trees decreased with increasing age.
The taper curves obtained for Paraná and for Santa Catarina differed, most likely due to different silvicultural treatments applied to the stands.

The identity test proposed by GRAYBILL (1976) was initially applied, comparing all of the 


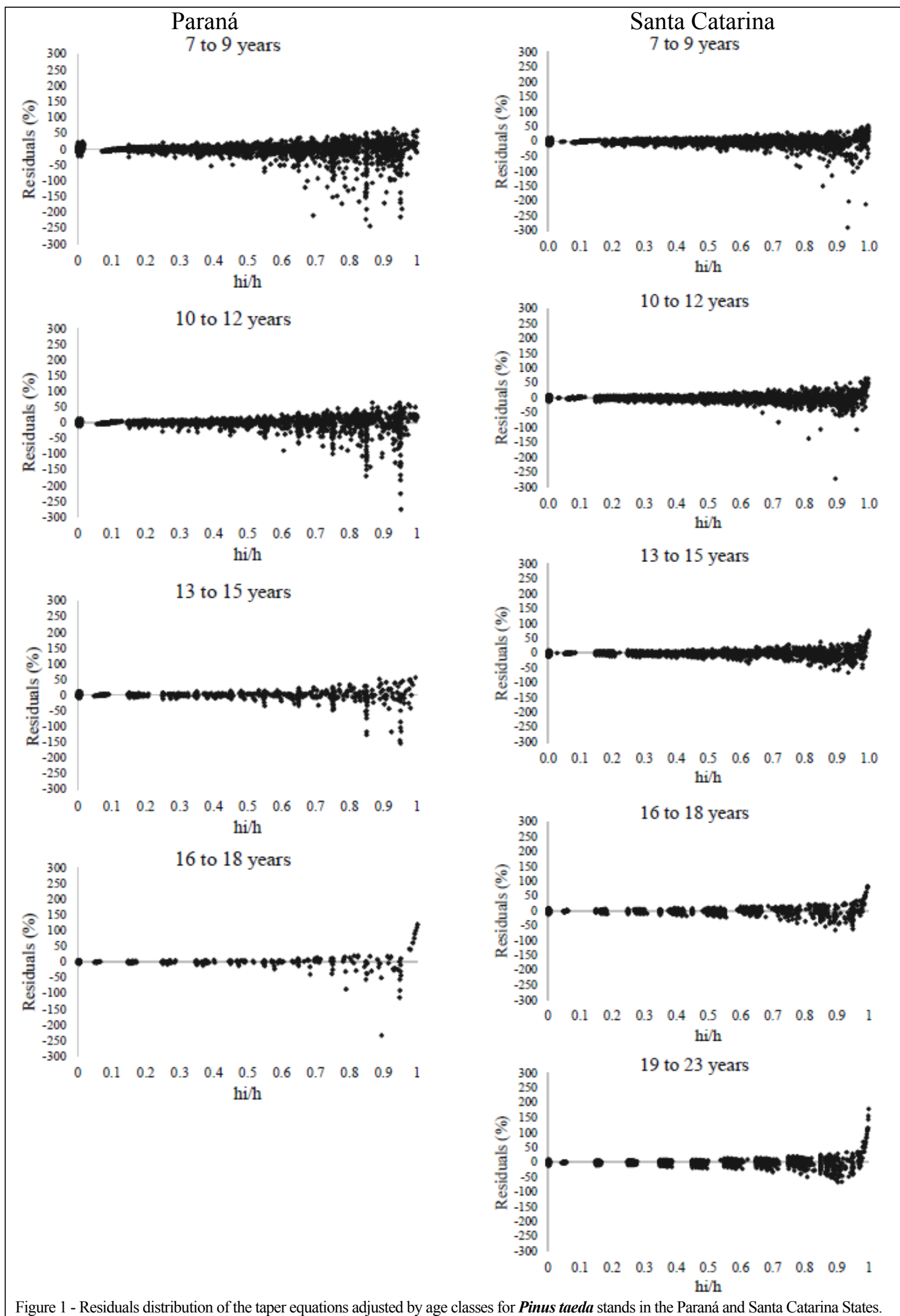

Ciência Rural, v.46, n.7, jul, 2016. 


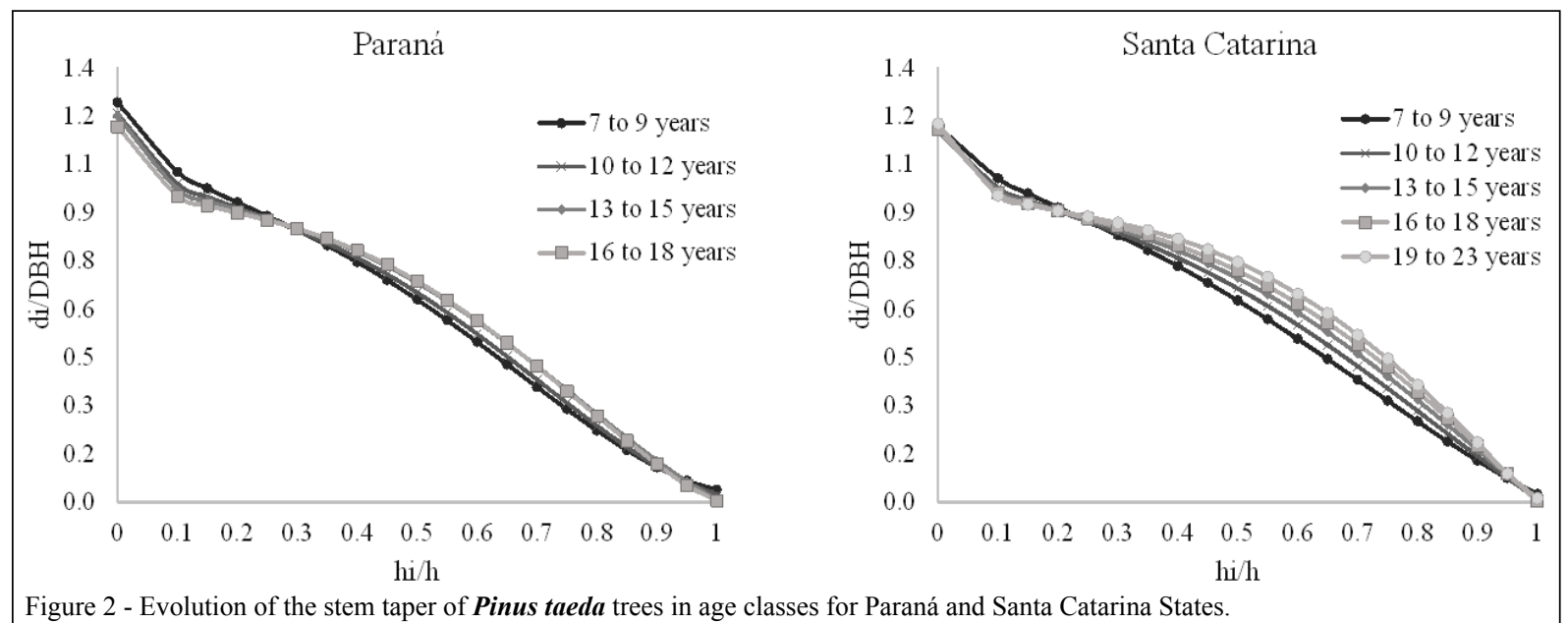

taper curves fitted for each age class and for the entire data set, inserting all ages (general model). The $p$ value (probability or $\alpha$ error) found for the tests was lower than 0.95 , rejecting the $\mathrm{H}_{0}$ null hypothesis for both data sets, i.e., the sum of the squared residuals for the age classes was not statistically equal to the sum of the squared residuals of the general model. It was therefore possible to conclude that the taper curves were different at the various ages, showing that the trees changed their form with increasing age. In applying the same test for the curves grouped in pairs, all were found to be statistically different, both for the data for Paraná and for Santa Catarina, i.e., the tree form significantly varied from one age class to the next.

\section{Form factor analysis}

The artificial form factor had high values at the younger ages, which indicates the effect of using $\mathrm{DBH}$ as reference diameter. Usually, the younger trees had well-tapered stems, thus the basal diameter of the tree was much greater than the DBH, making the tree volume very close to or even greater than the reference cylinder volume (obtained based on $\mathrm{DBH}$ ), resulting in higher artificial form factor values. BURGER et al. (1980) reported similar results for Araucaria angustifolia trees and stated that this reduction in the artificial form factor does not mean that the tree form is worsening, as this factor does not directly represent the geometric form of the tree, but is a reduction factor for calculating the volume.

Figure 3 shows the evolution of the form factors with tree growth. For the stand located in Paraná at 18 years old, the form factors underwent a reduction because few trees were sampled at this age. The form factor increased as the trees grew older and both the natural and artificial form factors tended to stabilize over time. Based on this determination, and as reported by FERREIRA (1999), the indiscriminant use of a single form factor at any age can generate considerable errors in obtaining volumetric estimates and in studying tree form.
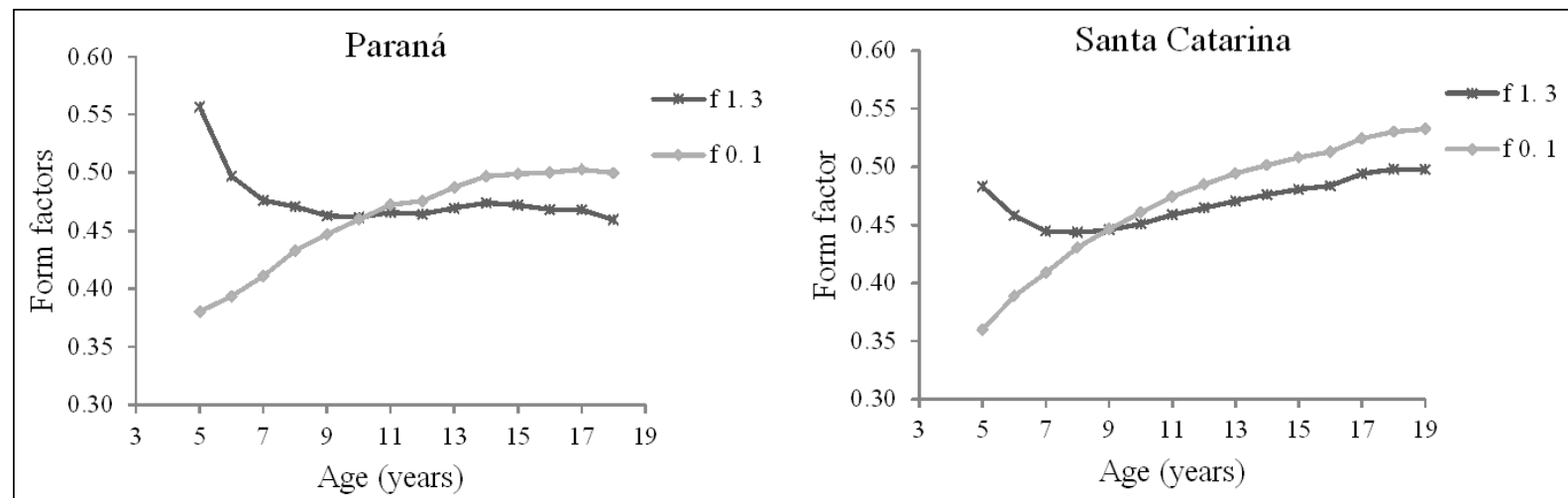

Figure 3 - Evolution of the natural $\left(\mathrm{f}_{01}\right)$ and artificial $\left(\mathrm{f}_{13}\right)$ form factors for Pinus taeda trees in the Parana and Santa Catarina States.

Ciência Rural, v.46, n.7, jul, 2016. 


\section{CONCLUSION}

The fitted taper model represented adequately the evolution of trees stem form, showing that the tree stems were more tapered at early ages, improving their form with increasing age. The taper curves developed for the age classes, in both stands, were statistically different.

Both the natural and artificial form factors are highly affected by age, where the change in stem form is greater in younger trees.

Finally, it was concluded that taper functions should be fitted by age classes to be more effective in estimating the assortment in forest stands, and the use of form factors without considering age should be avoided.

\section{REFERENCES}

BURGER, D. et al. Estudo do desenvolvimento da forma de Araucaria angustifolia com relação a idade. In: ENCONTRO DA IUFRO (INTERNATIONAL UNION FOR FORESTRY RESEARCH ORGANIZATION), 1980, Curitiba, PR. Anais.. Curitiba: IUFRO, 1980. p.320-329

FERREIRA, S.O. Estudo da forma do fuste de Eucalyptus grandis e Eucalyptus cloeziana. 1999. 132f. Dissertation (Masters in Forest Engineering) - Universidade Federal de Lavras, Lavras, MG.

FIGUEIREDO FILHO, A. et al. Taper equations for Pinus taeda in Southern Brazil. Forest Ecology and Management, Amsterdam, v.83, n.1, p.39-46, 1996. Available from: <http:// www.sciencedirect.com/science/article/pii/0378112796037061>. Accessed: Mar. 04, 2016. doi:10.1016/0378-1127(96)03706-1.

FIGUEIREDO FILHO, A. et al. Dynamic of stem taper and wood production in Araucaria angustifolia plantations. Cerne, Lavras, v.20, n.4, p.595-603, 2014. Available from: <http:// www.scielo.br/scielo.php? script $=$ sci_arttext\&pid $=$ S0 $104-$ $77602014000400013 \& \operatorname{lng}=\mathrm{pt} \& \mathrm{nrm}=$ iso\&tlng=pt $>$. Accessed Mar. 04, 2016. doi: 10.1590/01047760201420041386.

FIGUEIREDO FILHO, A. et al. Efeito da idade no afilamento e sortimento em povoamentos de Araucaria angustifolia. Floresta e Ambiente, Seropédica, v.22, n.1, p.50-59, 2015. Available from: $<$ http://www.scielo.br/scielo.php?script $=$ sci_arttext\&pid $=$ S2179$80872015000100050 \& \operatorname{lng}=$ pt\&nrm $=$ iso\&tlng $=$ pt $>$. Accessed: Mar. 04, 2016. doi: 10.1590/2179-8087.080114.

FINGER, C.A.G. et al. Funções de forma para Eucalyptus dunnii implantados na depressão central e encosta sudoeste do Rio Grande do Sul. Ciência Rural, Santa Maria, v.25, n.3, p.399-403, 1995. Available from: $<$ http://www.scielo.br/scielo.php?script=sci arttext\&pid $=\mathrm{S} 0103-84781995000300012 \& \operatorname{lng}=\mathrm{pt} \& \mathrm{nrm}=\mathrm{is}$ o\&tlng=pt $>$. Accessed: Mar. 04, 2016. doi: 10.1590/S010384781995000300012 .

FISCHER, F. et al. Exatidão dos modelos polinomiais nãosegmentados e das razões entre volumes para representar o perfil do tronco de Pinus taeda. Ciência Florestal, Santa Maria, v.11, n.1, p.167-188, 2001. Available from: <http:// cascavel.ufsm.br/revistas/ojs-2.2.2/index.php/cienciaflorestal/ article/view/503/389>. Accessed: Mar. 04, 2016.

FRIEDL, R.A. Dinâmica e prognose da forma dos fustes em povoamentos plantados de Araucaria angustifolia (Bert.) 0 . Ktze. 1989. 167f. Dissertation (Masters in Forest Engineering) Universidade Federal do Paraná, Curitiba, PR.

GRAYBILL, F.A. Theory and application of the linear model. Belmont: Duxbury, 1976. 704p.

HRADETZKY, J. Analyse und interpretation statistisher abrängerkeiten. Baden-Wüettemberg: Mitteilungen der ForstlichenVersuchs-und Forschngsanstalt Heft, 1976. N.76.

KOHLER, S.V. et al. Modelos de afilamento para Pinus taeda por classes de idade. Floresta e Ambiente, Seropédica, v.20, n.4, p.470-479, 2013. Available from: <http://www.floram.org/ articles/view/id/527ce42a5ce02a011a000005>. Accessed: Mar. 04, 2016. doi: 10.4322/floram.2013.039.

LARSON, P.R. Stem form development of forest trees. Washington: Forest Science Monograph, 1963. p.1-41.

MACHADO, S.A. Influência da idade na forma do fuste de Araucaria angustifolia em plantações no Brasil. In: SEMINÁRIO SOBRE ATUALIDADES E PERSPECTIVAS FLORESTAIS: O USO DE FUNÇÕES DE FORMA DE TRONCO EM ESTUDO DE VOLUMETRIA DE ESPÉCIES FLORESTAIS, 5., 1982, Curitiba, PR. Anais... Curitiba: EMBRAPA, 1982. p.51-55.

MACHADO, S.A. et al. Comparação de modelos de afilamento do tronco para diferentes idades e regimes de desbaste em plantações de Pinus oocarpa Schiede. Boletim de Pesquisa Florestal, Colombo, n.48, p.41-64, 2004.

MÔRA, R. et al. Análise de diferentes formas de ajuste de funções de afilamento. Scientia Forestalis, Piracicaba, v.42, n.102, p.237-249, 2014. Available from: <http://www.ipef.br/ publicacoes/scientia/leitura.asp? Article $=08 \&$ Number $=102>$. Accessed: Mar. 04, 2016.

REGAZZI, A.J. Teste para verificar a identidade de modelos de regressão e a igualdade de alguns parâmetros num modelo polinomial ortogonal. Revista Ceres, Viçosa, v.40, n.228, p.176-195, 1993. Available from: <http://www. ceres.ufv.br/ojs/index.php/ceres/article/view/2190/226>. Accessed: Mar. 04, 2016. 